\title{
Frontline nurses' sensemaking during the initial phase of the COVID- 19 pandemic in 2020 Aotearoa New Zealand
}

Catherine $\operatorname{Cook}^{1,3}, \mathrm{PhD}, \mathrm{RN}$, Associate Professor, School of Clinical Sciences

Margaret Brunton ${ }^{2}, \mathrm{RN}, \mathrm{PhD}$, Associate Professor, School of Communication, Journalism \& Marketing

Marie K. Chapman ${ }^{2}$, BComm (Communication Management), School of Communication, Journalism \& Marketing

Matt Roskruge ${ }^{2}$, PhD, School of Economics \& Finance
Citation

Cook, C., Brunton, M., Chapman, M. K., \& Roskruge, M. (2021). Frontline nurses' sensemaking during the initial phase of the COVID-19 pandemic in 2020 Aotearoa New Zealand. Nursing Praxis in Aotearoa New Zealand, 37(3), 41-52.

https://doi.org.10.36951/27034542.2021.034

${ }^{1}$ Auckland University of Technology, Auckland, Aotearoa New Zealand

${ }^{2}$ Massey University, Auckland, Aotearoa New Zealand

${ }^{3}$ Corresponding Author: catherine.cook@aut.ac.nz

\begin{abstract}
The aim of this study was to identify the COVID-19 pandemic impacts on nurses' sensemaking and explore resilience and mitigation strategies nurses adopted to sustain their wellbeing. Frontline clinical nurses are an essential population within the health workforce. Although they are educated to deal with the many challenges working in health presents, this pandemic has created new stressors and vulnerabilities, placing strain on their wellbeing. This article reports on the qualitative data from a national mixed methodology study undertaken between October and December 2020. Twenty-nine interviews were conducted remotely using Zoom and telephone with nurses in a wide range of clinical front-line roles. Data were analysed thematically drawing from the theoretical lens of sensemaking, and related concept of liminality. Findings identified that early in the pandemic, participants who were frontline nurses prioritised patient care while negotiating shifting uncertainties, fear, under-resourcing, and variable leadership. They watched the unfolding international crisis and anticipated that we, in Aotearoa New Zealand, faced a similar disaster. Amidst significant stressors, they endured separation from their families while acting as substitute family for patients and residents isolated from whānau. Six themes were identified: liminality; teamwork and leadership; relational dynamics; health and safety precarity; care ethics; and heroes and pariahs. The study highlights that organisational culture, communication, and clinical leadership either fractured or strengthened nurses' professional commitment.
\end{abstract}

Keywords / Ngā kupu matua: altruism / te whakaaro atawhai i ētahi atu; COVID-19; frontline nurses / ngā tapuhi i te aroākapa o ngā mahi; leadership / te mahi arataki; liminality / panonitanga o te āhua tangata; sensemaking / te mātai àhuatanga; wellbeing / hauora

\section{Te Reo Māori translation}

Te mātai āhuatanga a ngā tapuhi i te aroākapa o ngā mahi āwhina tūroro i ngā marama tuatahi o te mate urutā o Covid-19 i 2020 i Aotearoa New Zealand

\section{Ngā ariā matua}

Ko te whāinga ia o tēnei mātainga tūāhua he tautuhi i te pānga o te urutā o COVID-19 ki te mātainga āhuatanga a ngā tapuhi, he tūhura hoki i ngā rautaki tū pakari, whakangāwari hoki a ngā tapuhi kia mau tonu tō rātou hauora. He taupori taketake ngā tapuhi i te aroākapa o ngā mahi āwhina tūroro i roto i te kāhui kaimahi hauora. Ahakoa kua ākona rātou mō ngā tini wero ka tūponotia e te hunga mahi i te ao hauora, i tēnei o ngā urutā kua puta ake ētahi atu pēhitanga, whakaraeraetanga hoki, ā, hei whakataumaha ēnei āhua i tō rātou hauora. Tā tēnei tuhinga he tuku pūrongo mō ngā raraunga inekounga mai i tētahi rangahau tikanga-maha i kawea i waenga i ngā marama o Whiringa à- 
nuku/Oketopa me Hakihea/Tīhema 2020. Rua tekau mā iwa ngā tapuhi i kawea mā te whakamahi i Zoom me te waea hei kōrero ki ngā tapuhi i ngā tūnga āwhina tūroro i te aroākapa o ngā mahi. I āta tātaritia ngā raraunga i runga i ngā kaupapa, me te whakamahi i te arotahi ariā o te mātai āhuatanga, me te ariā tūtata o te panonitanga taumata tangata. I tautuhitia i roto i ngā kitenga ko te hunga whai wāhi mai i ngā marama tuatahi o te urutā ko te tapuhi whai wāhi ki te uiuinga i whakaraupapa i te tiaki tūroro hei whāinga matua, me te kawe i ngā whakaaro rangirua, i te mataku, i te kore rauemi, me te mahi hautū tāpokopoko i ētahi wā. I mātaki rātou ki ngā raruraru nui i te ao katoa, me te whakaaro tērā pea ka pā he aituā nui pērā ki a tātou i Aotearoa. I roto i ngā āhuatanga whakataimaha nui, i kawea e rātou te taumaha o te noho wehe i te whānau, me te noho hei whānau kairīwhi mō ngā tūroro me te hunga noho taratahi i ō rātou whānau. E ono ngā kaupapa i tautohutia: ko te panonitangata o te āhua tangata; te mahi ā-tira me te mahi arataki; ngā pananga hononga; te uaua o te hauora me te haumaru; ngā tikanga tiaki matatika; ko ngā tuahangata me ngā tāngata hē. Kei tēnei rangahau ka kitea nā te ahurea o te whakahaere, te whakawhiti kōrero, me ngā arataki mō te mahi āwhina tūroro, ka heke rawa rānei, ka piki rānei te whakamaunga ngaio o ngā tapuhi.

\section{Background}

The advent of COVID-19 rapidly gathered momentum as the global transmission of the coronavirus SARSCOV-2 on populations began to display evidence of significant morbidity and mortality. The unforeseen acceleration particularly required frontline nursing and medical staff to confront with haste the reality of personal risk and life disruption. The international accolades for Aotearoa New Zealand's response (Jefferies et al., 2020) belies the impact on our workforce. A New Zealand Nurses Organisation spokesperson expressed concern at nursing's exclusion from expert advisory groups and stated, “...health-care incidents are reviewed through a patient-centric lens, rather than a health and safety framework focused on risk and harm to workers" (Weston, 2020, p. 34). Aotearoa New Zealand entered the pandemic with a neoliberal health system eroded by successive governments (Barnett \& Bagshaw, 2020). Ministry of Health assurances of adequate personal protective equipment did not accord with the realities for many health professionals (McGuinness Institute, 2020).

The first case of COVID-19 was diagnosed in Aotearoa New Zealand on 28 February 2020. By 21 March the government announced a four-tiered alert level system and by 25 March the whole country was moved to the highest alert level four, with everyone mandated to go into isolation 'bubbles' - small groups domiciled together. All except essential services closed and people were required to stay in their residential area, only leaving home to shop and exercise outdoors. International borders closed with few exceptions apart from residents and citizens. On 29 March the first COVID-19 related death occurred.
By 8 June there were no community cases of COVID19 , although there were further infections due to border incursions, resulting in additional lockdowns in 2020 (New Zealand Government, n.d.). At the time data was collected for this study, between October and December 2020, Aotearoa New Zealand was at Alert level 1, with people able to move freely within the country. By the end of December 2020 there had been 2162 cases and 25 deaths (World Health Organization, n.d.). These cases are people, linked to families and wider networks, the lives of whom have impacted many of our approximately 58,000 nurses.

\section{Conceptual frameworks}

The pandemic thus far has added considerable pressure to nurses' professional and personal lives, impacting their wellbeing (Labrague \& De Los Santos, 2020; Rosser et al., 2020; Shanafelt et al., 2020). To analyse disruptions to nurses' wellbeing and their resilience and mitigation strategies, we applied the overarching theoretical concept of sensemaking (Weick at al., 2005), and the related concept of liminality (Van Gennep, 1960).

The pandemic has created a complex and fastmoving context, requiring us to continuously reframe and make sense of new and emerging realities. Such "[e]xplicit efforts at sensemaking tend to occur when the current state of the world is perceived to be different from the expected state of the world" (Weick et al., 2005, p.409). Our usual actions and activities are disrupted and we are required to adapt in a way that is often beyond our existing repertoire and knowledge. Sensemaking requires us to relate to the unknown through experimenting with alternative actions, and then reviewing and revising these 
actions as we experiment with what works in a shifting reality (Ancona, 2012).

Noticing, meaning-making, and action are intertwined aspects of sensemaking (Weick at al., 2005). An illustration of noticing is that during this pandemic, people, including nurses, have been overwhelmed with huge volumes of information, at times making it hard to recognise and prioritise key messages. Cognitive exhaustion may impede people's ability to keep up to date with shifting information (Arnetz et a., 2021). Throughout the pandemic thus far we have seen vastly divergent meaning-making about COVID-19, between individuals, communities, and nations. This aspect of sensemaking has impacted health professionals in wide-ranging ways. For example, Morgan (2020) argues that in the UK context, the heroic metaphor for frontline health workers is used to draw attention away from political failings that resulted in thousands of deaths. Berger (2021) concurs, positing that the heroic metaphor applied to healthcare workers has an underbelly of public and political expectation that these professionals will put themselves in harm's way, similar to the expectations of service personnel. People make sense of their world through action, and yet action has been severely curtailed through lockdowns and numerous measures to curtail viral spread. Aquilia et al. (2020) highlight numerous ways clinical nurse leaders supported their teams to adapt to novel circumstances. These adaptations were made by nurses 'on the floor' as more senior managerial leaders were not physically present to participate in 'on the spot' decision-making.

Liminality, a concept drawn from anthropology, provides a lens for understanding transitions. Liminality is a three-part process involving separation from the known; a liminal period that is a destabilising and disorientating threshold where people's status is ambiguous socially and structurally; and ultimately but not always, reassimilation into a 'new normal' (Van Gennep, 1960). This non-linear process is affected by extrinsic and intrinsic factors. The concept is widely used in health research to consider disruptive events, including COVID-19 (see for example Awdish, 2021; Jackman et al., 2020; Wayland, 2021). In a period of liminality, the sense of communitas - a shared identity - can provide solidarity and foster resilience.

This study aimed to identify the COVID-19 pandemic impacts on nurses' wellbeing and to explore resilience and mitigation strategies nurses adopted to sustain their wellbeing. Although from an international perspective Aotearoa New Zealand was applauded early in the pandemic as an exemplar of an elimination strategy (Robert, 2020), it is essential to capture the significant cognitive and emotional labour for frontline nurses as they adapted to this early phase of the pandemic.

\section{Method}

These qualitative data are part of a larger dataset drawn from a national mixed methodology study in Aotearoa New Zealand. The qualitative analysis was informed by a social constructionist approach, to investigate the experiential dimensions of nurses' lives. The social constructionist paradigm focuses on how meanings are forged, sustained, negotiated, and dismantled (Burr, 2015).

\section{Participants}

Respondents in the online survey distributed by the New Zealand Nurses Organisation were invited to signal their interest in a follow-up qualitative interview via Zoom, resulting in 29 participants. The study sample comprised of 28 registered nurses and one midwife. Participant ethnicities were two Māori, one Korean, one Taiwanese, one Canadian, one Scandinavian, two British, two Dutch, and 19 Pākehā (New Zealand European). Participants ranged in ages from mid-twenties to late sixties, working throughout the country and in a wide range of settings from primary to tertiary level care and managed isolation facilities.

\section{Data collection}

Potential participants were emailed, with an accompanying information sheet, to introduce the interviewer, organise a telephone call to address any queries, and arrange an interview time. Semistructured interviews were undertaken. Examples of interview prompts are as follows: describe a situation that is significant for you that reflects how the COVID19 pandemic has affected 1) relationships with colleagues and 2) relationships in your personal life; describe a situation that in some way reflects a shift or heightened awareness of your perspective, values or beliefs because of nursing through the COVID-19 pandemic; what were some of the challenges you faced keeping yourself and your whānau (family) as healthy and safe as possible? 


\section{Data analysis}

Data were analysed using Braun and Clarke's (2006) thematic analysis, which is compatible with social constructionist approaches. This process involves identification, analysis, and representation of themes. The process involved both inductive and deductive analysis as analysis was driven by data and theory (Fereday \& Muir-Cochrane, 2006). Thematic analysis requires meticulous and equal attention to all data initially. The first three authors familiarised themselves with the data separately and then collaboratively, coding initial interesting features in the dataset, collating these into potential themes and generating a thematic map, culminating in the selected themes.

\section{Ethical considerations}

The study was approved by Massey University Human Ethics Committee. Participation was voluntary. Participants were informed about the study; respect for confidentiality and anonymity were discussed; and verbal consent was obtained before interviews. The online interviews were conducted with adherence to international recommendations (Lobe at al., 2020). The digital interview recordings were transcribed under the auspices of a confidentiality agreement.

\section{Findings}

Six themes were identified from the data: liminality: participants were rapidly thrown into an uncertain space where the known practice patterns were uprooted; teamwork and leadership: participants' navigated fragmented leadership; relational dynamics: participants and their families made sacrifices in their personal lives; health and safety precarity: participants managed gaps in protective gear and safety protocols; care ethics: participants endured the moral distress of disrupted care practices; heroes and pariahs: participants weathered the troubled identity of being frontline workers.

\section{Liminality}

The advent of COVID-19 rapidly gathered momentum internationally with evidence of significant mortality, which demanded a swift response. The following quote highlights what was evident across the dataset; nurses' shift from being somewhat oblivious to world events to being hyper-cognisant of imminent change:

I hadn't been taking too much notice of what was going on, I'd realised, and suddenly there was a pandemic. Gosh, I suddenly realised that there hadn't been a pandemic since 1918. There was that sudden sort of awareness. I can get quite anxious, I sort of had to go away and have a little wee cry and talk to the infection control nurse, because suddenly New Zealand was going to be infected by me. I'd kind of catastrophised that. [\#14, district nurse seconded for COVID-19 role]

Frontline nurses described their preparedness and then waiting in emptied-out hospitals for the virus to arrive:

You were constantly trying to get your head around what's going to happen, and what's potentially going to happen. Everyone was a little bit anxious. I wasn't particularly freaking out. I suppose it was like a wary... you're just waiting for the tidal wave to happen. There was kind of this nervous apprehension - I think between us and ED [emergency department]. Those first days, after we went into level four, for about I think a week and a half to ten days, it was just so eerily quiet. We just weren't getting any patients in at all. [\#9, high dependency unit]

Participants recalled the strong emotions they and all those around them experienced as they tried to make sense of an uncertain future:

There was one overriding kind of feeling and that was anxiety. No matter what role we were playing, whether it was staff, the managers of staff, whether it was residents, whether it was their families. Everybody was anxious. So staff, they were anxious on probably a few fronts. They were anxious about the thought that they might bring the virus with them to work unwittingly. They were also anxious that they might pick it up at work and take it home to their families. So a lot of them, including myself, we had to curtail our activities at that stage. [\#17, residential care manager]

The experience of liminality - an in between space where old patterns do not work, but there is no clear path forward - was evident as participants described their surprise at how ill-prepared their services were for a pandemic:

...organisational lack of readiness: I just assumed that there would be a pandemic plan that would be actioned, but it felt like there wasn't anything on paper, like no 
guide...particularly in this part of the world after SARS a few years ago, I felt that somewhere they would dust off a pandemic plan that they had written up and enact it. Maybe they did, but it didn't feel like that happened, it's kind of just winging it really. [\#20, seconded to COVID response team]

Participants all spoke of the often-radical reorganisation of their social networks and the new vocabulary that accompanied the pandemic:

...the new language; the bubble was a very new term for all of us too even as health professionals. Like, if I said to you, "we're gonna be talking about a bubble in 18 months," you'd be thinking, "well what the hell's that"? For me in the hospital that became my big bubble. [\#1, charge nurse]

Although anxiety was a feature of this liminal phase for many participants, a minority of participants felt well prepared, from both experience and temperament, to adapt with resilience to the possible impending disaster:

I didn't get into nursing to run at the first sign of a problem, and we know that things happen. Like I worked through the earthquakes in Christchurch, and we had a trauma centre set up at the hospital that I worked at and I was a part of that. It was very traumatic, but it also set me up. It showed me what I did made a difference. [\#29, residential care]

Across the data-set participants spoke of noticing the differing contexts for colleagues that manifested in wide-ranging responses to the pandemic:

I didn't even find it that hard to be honest. The next thing I'd like to do is disaster nursing .... I didn't find it that mentally or emotionally challenging. But then, we didn't have people dying daily of COVID like they've got overseas. I think that would be such a different kettle of fish. It [the pandemic] brought us [emergency department team] together and it also highlighted which nurses were good at working with constant change and which nurses struggled. It was an eye-opener into people's personalities actually. [\#27, high dependency unit]

The data highlighted that participants experienced the rapid disruption of life as they had known it, with accompanying anxiety affecting every area of their lives. This distress was more evident for participants when they perceived they were in an ill-prepared workplace with poor communication, and when they considered their family members and patients were particularly vulnerable; issues explored below. Few participants recounted escaping distress.

\section{Teamwork and leadership}

Participants' recollections of the initial lockdowns were largely dependent on the extent to which they experienced positive leadership and teamwork. Through this uncertainty, nurses looked to managers and leaders for both direction and support as they navigated trying to make sense of the ever-shifting environment. Clinical, 'on the ground' leadership had a 'make or break' impact on teams. Participants expressed that this leadership had most impact as there was a strong sense of being dislocated from senior leaders who were physically absent; a point emphasised by the following participant:

We had to look after each other because there was nobody else to do it. The managers led us but they weren't in there, if you know what I mean. They were behind closed doors. The managers that came in, they didn't go into the rooms. They were sort of out in the foyer or on the computer; even though they verbally were absolutely fantastic.... Unless you were actually on the floor you didn't understand.... We were initially told how to dress and use our PPE gear and we nurses took it a step further... It was a unique situation whereby the [frontline] nurses in a lot of ways, we were the ones that led it, because even though we were told what to do, there's nobody going to be coming in and slapping our hands because they didn't want to be in there in case they caught anything. It was us nurses that backed each other up. [\#10, seconded to work in COVID area]

Participants repeatedly highlighted the gaps between remote directives and the clinical capacity to implement mandates:

Information overload - I think there was too much information slammed at us - way too much information. You were just inundated. You had updates from your own managers. You had updates from the hospital, managers, and communications. You came back after a couple of days and it was just update, update, update. In the end I got to the point where I 
was just reading the last one. You can't constantly keep reading all that information. [\#9, high dependency unit]

Typically, participants had a sense of 'you had to be there' to have an appreciation of the clinical challenges and requirements, and directives were not necessarily fit-for-purpose. A clinical leader in residential care spoke of her positive evaluation of her role in the stabilising of her workforce and resident group, despite the sense of feeling undervalued by senior managers:

\section{At a facility level just within our group, what did it mean to be the [lead] RN? How did I feel? At times, frustration. I think I led a good team. I think our team was led well because they were happy, the residents were happy, the care staff on the whole were happy. You got the old 'speed-wobble' every now and then, but I think we came through really well. So, at facility level, I would just say respected at facility level. From a management level, we had no value really. [\#18, residential care clinical manager]}

Participants spoke of initiatives either they or their clinical leaders had taken to enhance teamwork during the lockdown periods. A participant in primary healthcare described how the simple measure of closing the clinic and eating communally increased morale:

It meant that then we could actually have our lunch breaks together and then we would all sit and talk. That never happens. We're always just talking in the hallway. It's just that awful type of system that's very westernised so you're talking on the run. But then because of COVID we were then able to properly sit with each other and eat. It's just a better way to be. It reduces stress because you see your colleagues in a relaxed state and then you connect a lot more. [\#7, primary healthcare]

A clinical leader found that colleagues meeting together regularly enhanced a sense of collegiality and support:

We had regular huddles a couple of times during the day just to touch base with the charge nurses as a group, and it was all questions that would come up. In the beginning a lot of it was around pay, you know, nurses, we were sending nurses home on COVID leave; vulnerable nurses, immuno- suppressed, waiting on swabs; and it was so many questions that we just didn't know. So that was a good strategy for us. [\#1, charge nurse]

Across the dataset participants highlighted that their clinical experience during the initial lockdowns was positive when there was a strong sense of local clinical leadership, even if there was a perception of dislocation between clinical leaders and the remote leadership from more senior colleagues, district health boards and government.

\section{Relational dynamics}

Participants emphasised the impact of being a frontline worker on relationships with immediate family members; managing their distress and sometimes knowing they were going against families' wishes was commonplace:

My daughter was almost crying. She said, "You're so excited to get into the real dangerous part. Keep inside. Why should you go there?" My husband was quite upset too, "Why you, why you?" I explained to him I have to do it as a nurse otherwise my pride will go away so I have to go and I'll keep myself safe using PPE so I'll make sure of my safety as well as God protecting me. So my husband accepted and my daughter accepted all things as they know my passion as a nurse. [\#21, senior surgical nurse]

The dataset showed the sacrifices and lengths frontline nurses went to in their personal lives, to keep whānau safe:

I had already decided that I would self-isolate. We have a spare room. Like a lot of us nurses did, we had a routine; like if we couldn't shower at work, we would get naked in the shed. We just had all these steps into the house to try and alleviate my own whānau's stress about it all. They were pretty on edge knowing that I could potentially bring something home. [\#22, surgical ward]

Participants who were in coupled relationships described planning how to decrease risk to each other and their communities by reducing their contact with each other:

A week or two before things got really bad, she [charge nurse] said, "if we need people to go and work with COVID patients you will be," well, her words were, "the first cab off the rank." How did I feel? And I said, "no problem." 
From that day on my husband [also an essential worker] and I slept in separate bedrooms. We had separate bathrooms. Made sure that if I did have to work in that environment it minimised the risk of passing anything on and I limited contact with my children and my grandchildren from that time on. I was preparing myself before we actually had to go and do anything really. [\#29, residential care]

Participants' commitment to their community meant they purposefully kept their bubble as small as possible, and this undertaking meant they bore the effects of psychological isolation:

I think one of the big ones [challenges] was definitely the lack of support and isolation I felt at the end of a shift. My husband still worked. He was working with [essential service], so he was out during the day until early evening. I'd come home from a particularly difficult shift, and I was on my own.... I felt like I couldn't reach out to anybody. [\#23, general surgery]

Participants included those working in residential care who chose to live onsite through the initial lockdown, with the sacrifices this entailed:

It was hard emotionally because I couldn't see my children and my granddaughters, but because we were a small facility with only two RNs and one was a clinical manager and myself, we knew we had to step up and keep ourselves 100 percent isolated because if anything happened, we were on our own. We both knew that going in. I was on my own. I actually was living onsite during that time. [\#18, residential care clinical manager]

The dataset demonstrated nurses' altruism during the first wave of the pandemic in Aotearoa, which often meant curtailing their own needs for intimacy and support to increase safety for their networks.

\section{Health and safety precarity}

Participants' accounts varied widely in terms of their sense of personal safety in the workplace. There was no uniformity in participants' access to, and education about the use of protective gear. Participants also had diverse experiences around organisational leadership pertaining to the wellbeing and comfort of frontline staff. Participants expressed surprise at what appeared to be ad hoc consistencies:
I felt, at times, that New Zealand is so small that there could have been a more collective approach to it, rather than it being left to the individual. You sort of got the impression it was left to individual DHBs, but then actually within our DHB, at times it felt as if it was just left to individual charge nurses to work out what was the best thing to do; and we hadn't done this before. [\#19, charge nurse]

Participants' access to PPE impacted in the level of fear they spoke of, especially where nurses believed PPE was withheld where it was needed:

I worked for the [initial] lockdown with district nurses, that was probably the scariest time because there was nothing really set up for us; we weren't wearing PPE, we were told we didn't need to wear PPE. [\#14, district nurse]

For virtually all participants, the shift from universal precautions to the rigours of donning and doffing PPE was a major learning experience. Few participants had colleagues who were experienced in an epidemic context:

We had a nurse that nursed through Ebola, so she brought her skills initially to show us the safest way to don and doff all your PPE gear and working in that environment. That was really helpful initially, otherwise it was like the blind leading the blind. [\#10, staff nurse dedicated COVID ward]

The requirement to don before attending to patients was an extraordinary practice for most nurses early in the pandemic. One participant spoke of an incident where staff prioritised immediate patient care over staff safety:

This particular lady collapsed on the toilet. She was very sick. Three of us had to rush in and get her off the toilet. She vomited on us. In the best scenario that's no good anyway. You have to do that. You can't leave her to die sitting on a toilet. If we got sick then so be it.... There was no PPE set up in the hallway... I think we just all jumped in and did what we had to do in that scenario, but we should have all been wearing PPE. [\#16, residential care] Leadership within practice setting was essential for staff safety:

I'm the nurse manager. I work very closely with the practice manager and also the owners of the practice. The owner said, "If 
there is any concern that we do not have enough PPE, or do not have PPE, we will not be seeing any patients at all." They said safety was the number one thing. If we didn't have the PPE we would shut. I think that was crucial in making myself and also my colleagues feel comfortable in being able to provide the care to the patients that we needed; knowing that actually, if we don't have what we need to protect ourselves, our bosses back us 100 percent that we will shut. So, that was really good. [\#8, primary healthcare clinical manager]

Frontline nurses' morale and teamwork were strengthened when nurses perceived organisational accountability for staff safety:

[Name of] DHB did a super job of making sure we had showers. After every shift we'd shower and change into clothes and if we worked in our COVID dirty ED, we wore hospital scrubs that they provided so we didn't have to take home uniforms. [\#25, emergency department]

However, some participants considered that the fundamentals of a safe working environment were not provided. The following example illustrates the absence of organisational preparedness for staff wellbeing:

The testing that we were doing in the community, and we tested five days of the week for like six weeks solid, and we were out in the community from nine till two every day. We were in rural locations where there was no toilet, and there was no shop; so if you didn't have food or water you starved and you just went thirsty. But the hardest part was not having a toilet. We were peeing behind trees and trying to pee in bushes. Two of our nurses got urinary tract infections because of holding on for so long, and not being able to pee when you need to type of thing. So, really, that was not good for us. [\#24, primary healthcare]

Participants repeatedly highlighted the uncertainty around supplies of PPE and hand sanitiser, which led them to working subversively to ensure adequate supplies to work with their vulnerable communities. The following participant, who worked in a primary care setting, justified her strategies, aimed to protect Māori and Pacific patients, who made up much of their patient group:
I'll be honest, I did do a little bit of squirrelling and I did tell some lies when I did fill out the online form, because I felt I needed to have some backup supplies, so that we continued to be able to provide the service to our vulnerable patients; because if we run out, that's it for our patients and we have to send them elsewhere, and you don't always get that continuity of care. [\#8, primary healthcare clinical manager]

Supply precarity and variable PPE education impacted participants' sense of safety and morale. Nurses made supply decisions at a local level as national supply initiatives were flawed.

\section{Care ethics}

Participants in residential and acute care settings described their distress at people being alone through illness and dying:

We still had all the other stuff going on; heart attacks; strokes; acute abdomens. I must admit our numbers went down initially but the people that were coming in were exceptionally sick; not necessarily with COVID but other things and they were unknown [COVID status]. There was a lot of distress amongst the nurses about that; that these people were basically left alone. As nurses during lockdown, we could not go into comfort them without being in full PPE. It was basically, we were encouraged to only be in there for the briefest amount of time possible because I would go out and help on the floor.... People [colleagues] were telling me their fears and their concerns and just seeing little old people without their family there when they were dying from their stroke or their heart attack or whatever. [\#25, emergency department]

Participants spoke of the extraordinary circumstances, and the empathy needed was additional to the usual caring:

It's not like nursing any other person in any other given situation. You had to have a lot of empathy ... you had to be totally on that patient's side. They basically were so frightened and so scared. They looked to you, and here you are all dressed up [in PPE]. Let alone if you've [a patient who has] got a psychiatric problem or if you've got delirium. [\#10, seconded to work in COVID area] 
Staff in residential aged care were acutely aware that they were substitute family for residents. They also struggled with the requirements for social distancing between residents; an impossibility with cognitively impaired residents unless they were confined to their rooms:

They were locked in their room for quite some time, and were I guess becoming a little bit frightened. I think we certainly had a lot more singing and a lot more fun amongst the staff, because we didn't have outside people coming in to do that kind of entertainment. I think we all did sort of join hands and try to make it a much more pleasant place to be.... We actually are their family... We can cover their role of the family for a short period of time. But, to lock someone in their room, and to isolate them from other residents, I think that's a really big thing to do to somebody without asking them if that's what they want. [\#16, aged residential care clinical manager]

Participants also highlighted the moral challenge of emergency situations, where staff had to ensure they have correctly put on PPE before attending to patients:
I had a few incidents like this where we did have someone cardiac arrest and I did put my foot down and say, "You have to PPE up before you go into the room. I know they're not getting compressions, but you've got to put your PPE on." Super hard to do. [\#28, emergency department]

Across the dataset participants' moral distress was evident, as well as numerous examples of their willingness to companion patients and residents, at times acting as de-facto family.

\section{Heroes and pariahs}

One of the terms that arrived with COVID was 'essential worker.' Social media were full of examples of frontline staff being treated both as heroes and pariahs. Participants described the range of responses to their role:

There was a lot of flak up here when the nurse who was in managed isolation and she had gone to the gym and tested positive. And there was a hue and cry about that, and I used to say to people, "Listen, these people, these nurses are putting their life on the line. She's entitled to go and relax, and she didn't know that she was infectious." To me there seems to be, and
I admit that I'm biased, that there are so many expectations of nurses but there is not the respect or the consideration. [\#11, agency]

Many participants shopped for their families as a safety strategy, as well as working, yet the option to go to the front of the queue was unpleasant for some:

The supermarket experience wasn't excellent. Some of our staff had very bad experiences at supermarkets, where if they went to the front of the queue because they were essential workers, they were verbally abused in the queue. I decided I was not going to tell anybody I was a nurse in the community. I didn't disclose I was a nurse. I waited in the queues. I didn't use the 'front oflines.' What we had seen a lot of was people being quite aggressive. [\#12, primary healthcare]

Participants who worked with known COVIDinfected people experienced ostracism by colleagues:

We were isolated and ostracised by all the other nurses and staff in the hospital as well. As soon as anybody knew we were a COVID nurse ... people are very frightened and they're scared, and they don't want anything to do with you. It's not personal. [\#10, seconded to work in COVID area]

One participant highlighted that there were not mechanisms in place in his context to protect frontline staff from family members' anger:

We were subject to a lot of abuse. "You don't know what you're doing; I'm going to ring my local MP [Member of Parliament]; I'm gonna ring Jacinda [Prime Minister]; I have rights." Terrible, terrible. And I got a lot of complaints, and a lot of formal complaints as well. And as a charge nurse I get quite distressed when I get a complaint about my ward because I think I do a really good job. But this situation [families unable to visit] was government driven. A lot of us still feel today that there should have been a filter that those complaints should have gone, [been] taken away from the ward and the nurses [to] deal with.... No, we got abused terribly, terribly, awful. A lot of swearing, $F$ this, $F$ that. [\#1, medical charge nurse]

Abundant data highlighted nurses' caring and suffering. Although they went beyond the usual professional boundaries to protect and nurture colleagues and patients, frontline staff often 
experienced ambivalent or hostile reactions within their communities.

\section{Discussion}

The purpose of this article is to identify the COVID-19 pandemic impacts on nurses' wellbeing and to explore resilience and mitigation strategies nurses adopted to sustain their wellbeing. The dataset indicates many exemplars of sensemaking; the process whereby people adapt to disruption and find momentum and purpose within their ever-changing reality. Crises provide an opportunity for improvisation and modification. Sahay and Dwyer (2021) in their exploration of sensemaking use the notion of job-crafting to conceptualise the ways that nurses during the pandemic have modified working practices to adapt to a rapidly changing context. This job-crafting at times entailed eschewing edicts from remote leaders when these decisions did not have currency in nurses' context. Job-crafting was evident in the current study. For example, in the residential care context staff considered it inhumane and unachievable to attempt social distancing with people with dementia and in some instances, staff lived in their facilities to become a bubble with the residents.

Nurses were cognisant of the gap between the government's insistence there were adequate PPE supplies and their clinical realities. These experiences echo Ancona's (2012) argument about the inherent challenges of sensemaking; comprehending and acting on the gap between aspirational commentary and actual capacity to deliver. Nurses in this study were subversive in ordering additional stock to ensure their staff and patients were not at risk due to unreliable supply issues. The data illustrate many instances of jobcrafting to boost team morale and promote collegiality. An aspect of job-crafting is changing one's relationship with aspects of a role to make it more meaningful. Across the dataset it was clear that nurses found additional purpose in their sense of being de-facto family members for patients and residents, including those who were dying.

Part of the sensemaking challenge in this pandemic thus far, has been the (mis)alignment between leaders' messages and the noticing and meaningmaking of clinical staff. There was a dissonance between the government's national narrative of 'everything is going well,' at times reiterated by remote-working DHB leaders, and the actual chaos experienced by frontline nurses. The outcome was that problems, such as inadequate supplies of appropriate PPE, were not being acknowledged, thus were not dealt with, compounding stress for frontline nurses (McGuinness Institute, 2020). These experiences are echoed by frontline nurses internationally. Shanafelt and colleagues (2020) conducted 'listening sessions' with a total of 69 interdisciplinary participants early in the pandemic in the US. They identified that staff confidence in healthcare systems was weakened when they perceived core aspects of their safety and comfort were left unattended. Key concerns were summarised as five requests: "hear me, protect me, prepare me, support me, and care for me" (Shanafelt et al., 2020, p. 2133). These requests are pertinent to the current study, where frontline staff often felt they occupied a different world than that spoken about from the podiums of the government's daily briefing. This discrepancy, also noted by Wayland (2021), increased the liminality for nurses; the sense that they occupied a world where their status, expertise, and vulnerability were contested.

In terms of feeling heard, clinical leaders in the current study perceived that their responsiveness in ensuring their teams felt heard, protected, prepared, supported, and cared for impacted positively on teams' morale. This local leadership also partially mitigated the frustrations of ill-fitting rhetoric from remote leaders. For example, local leaders fostered positive emotions through making explicit the emphasis on staff safety. They also prioritised communication and collaboration through regular 'huddles', shared staff meals, and were physically present. In our study, effective leadership appeared to entail senior nurses making the same personal sacrifices or greater than were expected of directcare staff, such as diminished contact with wider family. The importance of effective local leadership has been identified in other COVID-19 commentaries and studies (see for example Labrague \& De Los Santos, 2020; Moore, 2020; Prasad, 2020). Part of effective leadership involves recognising diverse contexts for staff and their families and responding to the differing levels of wellbeing and distress in team members in a person-centred manner (Rosser et al., 2020; Shanafelt et al., 2020). In the current study it was clear that frontline nurses experienced divergent emotions and meanings associated with their work, ranging from excitement; a sense of spiritual and 
professional purpose; through to personal chronic anxiety and family-related distress.

Across the dataset and echoed in the media and scholarly literature were examples of nurses being treated both as heroes and villains; heralded as angels and ostracised and blamed as vectors of transmission (Alves, 2020; Loveday, 2020; Song \& McDonald, 2021; Tomlin et al., 2020). The associations with altruism do not necessarily serve nurses well (Slettmyr et al., 2019). Wilson et al., (2020) argue that the superhero metaphor presupposes a transcendent being not requiring of decent wages, dedicated to high calibre care at personal cost. However, as identified in the current research, altruism also fostered resilience in some participants; a point noted in some studies (Specht et al., 2021; Wang et al., 2020). By 12 June 2020, 96 healthcare and support workers had acquired COVID-19 in their workplace; $6.4 \%$ of total infections (Ministry of Health, 2020). Appleton and colleagues (2021) note that the narratives of the 'team of five million' winning over the virus subsume the alternative realities of frontline workers' lives. While the $1 \mathrm{pm}$ briefings by the Prime Minister and the Director General of Health were seen by many as an act of social solidarity, for some nurses this was a type of reality television show with the lived experiences on the frontline smoothed over to create national confidence.

\section{Conclusion}

Metaphorically, frontline nurses in the first wave of the pandemic navigated a liminal space often with 'maps' provided by remote leaders that did not reflect their local landscape. These nurses endeavoured to make sense of this fast-moving context, finding workarounds and substitutes for even the most fundamental care practices, such as companioning dying people. They also had a morally distressing 'policing' role, such as being enforcers of patients' families having only remote contact. Frontline nurses found themselves in a liminal space, part of the newly minted category of essential workers, their presence both lauded and shunned. In their private lives they also weathered distancing themselves from personal sources of intimacy and comfort, keeping their bubble either small or even solitary, to protect kin.

Participants often expressed the dissonance between national rhetoric and their experiences of chaos and uncertain or unavailable resources and the concomitant safety concerns. These gaps included clear health and safety breaches. Participants' prior life experiences; personal support systems; beliefs and values; and sense of local leadership and teamwork accounted for the exemplars of resilience. Team adaptation occurred where clinical leaders were flexible, creative, optimistic, demonstrated they valued each team member, and had a 'hands-on' leadership ethic. The study highlighted the thorny issue of altruism in nursing when nurses are not resourced to care. In a gendered workforce, healthcare leaders must be cognisant that these essential workers are also typically providing crucial services within their families and communities.

\section{References}

Alves, V. (2020, April 11). COVID 19 coronavirus: Auckland nurse abused during supermarket trip. New Zealand Herald. https://www.nzherald.co.nz/nz/COVID19-coronavirus-auckland-nurse-abused-duringsupermarket-trip/AUK4VA5SQBTB4DMDLZJALEFZSA/

Ancona, D. (2012). Framing and acting in the unknown. In S. Snook, N. Nohria, \& R. Khurana (Eds.), The Handbook for Teaching Leadership, (pp. 3-19). SAGE Publications Inc

Appleton, N., Long, N., Aikman, P., Davies, S., Deckert, A., Fehoko, E., Holroyd, E., Jivraj, N., Laws, M., MartinAnatias, N., Roguski, M., Simpson, N., Sterling, R., Trnka, S., \& Tunufa'I, L. (2021). (Alter)Narratives of 'winning': Supermarket and healthcare workers' experiences of COVID-19 in Aotearoa New Zealand. Sites: A Journal of Social Anthropology and Cultural Studies, 17, 51-77.https://doi.org/10.11157/sites-id471

Aquilia, A., Grimley, K., Jacobs, B., Kosturko, M., Mansfield, J., Mathers, C., Parniawski, P., Wood, L., \&

Niederhauser, V. (2020). Nursing leadership during COVID-19: Enhancing patient, family and workforce experience. Patient Experience Journal, 7, 136-143. https://doi.org/10.35680/2372-0247.1482

Awdish, A. (2020). The liminal space. The New England Journal of Medicine, 383(e17). https://doi.org/10.1056/NEJMp2012147

Arnetz, J. E., Arble, E., Sudan, S., \& Arnetz, B. B. (2021). Workplace cognitive failure among nurses during the COVID-19 pandemic. International Journal of Environmental Research and Public Health, 18, 10394. https://doi.org/10.3390/ijerph181910394

Barnett, P., \& Bagshaw, P. (2020). Neoliberalism: What it is, how it affects health and what to do about it. The New Zealand Medical Journal, 33(1512), 76-84.

Berger, D. (2021, January 29). Up the line to death: COVID-19 has revealed a mortal betrayal of the world's healthcare workers [Blog post]. British Medical Journal. https://blogs.bmj.com/bmj/2021/01/29/upthe-line-to-death-COVID-19-has-revealed-a-mortalbetrayal-of-the-worlds-healthcare-workers/ 
Braun V., \& Clarke V. (2006) Using thematic analysis in psychology. Qualitative Research in Psychology 3, 77101. https://doi.org 10.1191/1478088706qp063oa

Burr V. (2015). Social constructionism ( $3^{\text {rd }}$ ed.). Routledge.

Fereday J., \& Muir-Cochrane E. (2006). Demonstrating rigor using thematic analysis: A hybrid approach of inductive and deductive coding and theme development. International Journal of Qualitative Methods 5, 80-92.

https://doi.org/10.1177/160940690600500107

Jackman, D., Konkin, J., Yonge, O., Myrick, F., \& Cockell, J. (2020). Crisis and continuity: Rural health care students respond to the COVID-19 outbreak. Nurse Education in Practice, 48, 1-8. https://doi.org/10.1016/j.nepr.2020.102892

Jefferies, S., French, N., Gilkison, C., Graham, G., Hope, V., Marshall, J., McElnay, C., McNeill, A., Muellner, P., Paine, S., Prasad, N., Scott, J., Sherwood, J., Yang, L., \& Priest, P. (2020). COVID-19 in New Zealand and the impact of the national response: A descriptive epidemiological study, The Lancet Public Health, 5(11), e612-e623. https://doi.org/10.1016/S2468-2667(20)30225-5

Labrague, L. J., \& De Los Santos, J. (2020). COVID-19 anxiety among frontline nurses: Predictive role of organisational support, personal resilience and social support. Journal of Nursing Management, 28, 16531661. https://doi.org/10.1111/jonm.13121

Lobe, B., Morgan, D., \& Hoffman, K. A. (2020). Qualitative data collection in an era of social distancing. International Journal of Qualitative Methods, 19, 1-8. https://doi.org/10.1177/1609406920937875

Loveday, H. (2020). Fear, explanation and action-the psychosocial response to emerging infections. Journal of Infection Prevention, 21(2), 44-46. https://doi.org/10.1177/1757177420911511

Ministry of Health. 2020. COVID-19 in health care and support workers in Aotearoa New Zealand. Author. https://www.health.govt.nz/publication/covid-19health-care-and-support-workers-aotearoa-newzealand\#: : text=The $\% 20$ first $\% 20$ case $\% 20$ of $\% 20 \mathrm{COV}$ ID,Zealand \%2C\%20as\%20at\%2012\%20June.

McGuinness Institute. (2020). Survey insights: An analysis of the 2020 NZNO PPE Survey. Author. https://www.mcguinnessinstitute.org/wpcontent/uploads/2020/05/20200518-Survey-Insights-Ananalysis-of-the-2020-NZNO-PPE-Survey.pdf

Moore, C. (2020). Nurse leadership during a crisis: Ideas to support you and your team. Nursing Times, 116(12), 34-37.

Morgan, M. (2020). Why meaning-making matters: The case of the UK Government's COVID-19 response. American Journal of Cultural Sociology, 8, 270-323. https://doi.org/10.1057/s41290-020-00121-y

New Zealand Government. (n.d.). COVID-19 alert levels and updates. https://COVID19.govt.nz/alert-levelsand-updates/

Prasad, M. (2020). On the frontlines of the coronavirus disease 2019 (COVID-19) Crisis-The many faces of leadership. JAMA Cardiology, 5(9), 983-984. https://doi.org/10.1001/jamacardio.2020.2240
Robert, A. (2020) Lessons from New Zealand's COVID-19 outbreak response. The Lancet, 5(11), e569-e570. https://doi.org/10.1016/S2468-2667(20)30237-1

Rosser, E., Westcott, L., Ali, P. A., Bosanquet, J., CastroSanchez, E., Dewing, J., McCormack, B., Merrell, J., \& Witham, G. (2020). The need for visible nursing leadership during COVID-19. Journal of Nursing Scholarship, 52, 459-461. https://doi.org/10.1111/jnu.12587

Sahay, S., \& Dwyer, M. (2021). Emergent organizing in crisis: US nurses' sensemaking and job crafting during COVID-19. Management Communication Quarterly, https://doi.org/10.1177/08933189211034170

Shanafelt, T., Ripp, J., \& Trockel, M. (2020). Understanding and addressing sources of anxiety among health care professionals during the COVID-19 pandemic. JAMA, 323, 2133-2134. https://doi.org/10.1001/jama.2020.5893

Slettmyr, A., Schandl, A., \& Arman, M. (2019). The ambiguity of altruism in nursing: A qualitative study. Nursing Ethics, 26, 368-377. https://doi.org/10.1177\%2F0969733017709336

Song, J., \& McDonald, C. (2021). Experiences of New Zealand registered nurses of Chinese ethnicity during the COVID-19 pandemic. Journal of Clinical Nursing, 30, 757-764. https://doi.org/10.1111/jocn.15607

Specht, K., Primdahl, J., Jensen, H., Elkjær, M., Hoffmann, E., Boye, L., Thude, B. (2021). Frontline nurses' experiences of working in a COVID-19 ward: A qualitative study. Nursing Open, 8, 3006-3015. https://doi.org/10.1002/nop2.1013

Tomlin, J., Dalgleish-Warburton, B., \& Lamph, G. (2020). Psychosocial support for healthcare workers during the COVID-19 pandemic. Frontiers in Psychology, 11, Article 1960, 1-7. https://doi.org/10.3389/fpsyg.2020.01960

Van Gennep, A. (1960). The rites of passage. Routledge.

Wang, H., Liu, Y., Hu, K., Zhang, M., Du, M., Huang, H., \& Xiao, Y. (2020). Healthcare workers' stress when caring for COVID-19 patients: An altruistic perspective. Nursing Ethics. 27, 1490-1500. https://doi.org/10.1177/0969733020934146

Weick, K. E., Sutcliffe, K. M., \& Obstfeld, D. (2005). Organizing and the process of sensemaking. Organization Science, 16, 409421.https://doi.org/10.1287/orsc.1050.0133

Wayland, S. (early online 2021). Editorial: Liminality and COVID-19 - what do we already know? International Journal of Mental Health Nursing, 30, S1, 1291-1292. https://doi.org/10.1111/inm.12909

Weston, K. (2020). Nurses' voices essential in COVID-19 reviews. Kai Tiaki Nursing New Zealand, 26(6), 34.

World Health Organization. (n.d). WHO health emergency dashboard: COVID-19 homepage. Author. https://COVID19.who.int/region/wpro/country/nz

Funding: Auckland Medical Council

Conflict of interest: None 